\title{
Conditions That Increase Latent Infection of Grafted or Non-grafted Tomatoes with Pseudomonas solanacearum
}

\author{
Kazuhiro NAKAHO*, Shigeo TAKAYA* and Yoshinori SumIDA*
}

\begin{abstract}
Seedling roots of the susceptible tomato cultivar Ponderosa and the resistant rootstock cultivars LS-89 and BF-Okitsu 101, Ponderosa or LS-89 scions grafted on Ponderosa or LS-89 rootstocks were inoculated with Pseudomonas solanacearum. At 14 days after inoculation, seedlings were indexed for disease severity and harvested to recover the bacterial pathogen from stem tissues. Many of the resistant and susceptible seedlings did not show wilting symptoms but were latently infected with $P$. solanacearum. As plant age at the time of inoculation increased, and inoculum concentration or incubation temperature decreased, the frequency of latent infection and wilting decreased. In LS-89, plants grown at $25 / 20^{\circ} \mathrm{C}$ (day/night) showed almost no symptoms but had latent infection at 20-75\%. Against five strains of $P$. solanacearum, the percentage of wilting and latent infection of seedlings was not different in Ponderosa or LS-89, but it was significantly different in BF-Okitsu 101. Both Ponderosa and LS-89 scions grafted on Ponderosa had nearly all wilted. However, Ponderosa scions gratfed on LS-89 wilted at nearly 60\%, whereas LS-89 scions grafted on LS-89 showed no wilting. Sixty-nine percent of these symptomless LS-89 scions and $35 \%$ of the symptomless Ponderosa scions did have latent infections. These results indicated that bacterial wilt of susceptible scions grafted on resistant rootstocks was due to a movement of the pathogen from latently infected rootstocks into the scions.
\end{abstract}

(Received September 20, 1995; Accepted December 20, 1995)

Key words: Pseudomonas solanacearum, tomato, resistance, rootstock, latent infection, grafts.

\section{INTRODUCTION}

Bacterial wilt caused by Pseudomonas solanacearum is a major constraint on the production of solanaceous crops in tropical, subtropical, and some warm temperature regions worldwide ${ }^{9}$. Control of the disease with chemicals $^{3)}$ and crop rotation ${ }^{5)}$ is ineffective, because the pathogen is particularly well adapted for surviving in the soil and rhizosphere ${ }^{6,19,27)}$. The use of cultivar resistance, therefore, is the most effective means of control ${ }^{28)}$.

Resistance to $P$. solanacearum in tomato is controlled by many genes, most of which are recessive ${ }^{31)}$. However, no fresh market tomato cultivar possesses both high resistance as well as high fruit quality ${ }^{17}$. To manage bacterial wilt, susceptible but high quality tomato cultivars have been grafted on resistant rootstocks. For this purpose, several highly resistant rootstock cultivars have been developed in Japan ${ }^{17,32)}$ and elsewhere ${ }^{29)}$.

Bacterial wilt has been reported in susceptible tomato cultivars grafted on resistant rootstocks ${ }^{22,26,33)}$. The disease in scions has been attributed to bacterial infection through wounds in scions produced during various farming practices ${ }^{13,14,18)}$, increase in pathogen virulence to resistant rootstocks ${ }^{1,12,21,23,26)}$, or local environmental and climatic conditions such as high ambient temperature ${ }^{12,16,30)}$.

Prior et al. ${ }^{24)}$ reported latent infections of resistant tomato plants. However, the relationship between such latent infections in rootstocks and the development of wilting symptoms in scions remains obscure.

The present study reports the recovery of $P$. solanacearum from stems of non-symptomatic tomato seedlings or scions with various resistances after rootinoculation and examines the effects of inoculum concentration, temperature, plant age and rootstocks on the development of symptomless infections.

\section{MATERIALS AND METHODS}

Plants. Two resistant tomato cultivars, LS-89 (Lycopersicum pimpinellifolium), a selection from Hawaii 799832), and BF-Okitsu 101 (L. esculentum), a selection from NC1953-64 $\mathrm{N}^{25}$, and a susceptible cultivar Ponderosa (L. esculentum) were used. LS-89 and BFOkitsu 101 have been used as rootstocks in Japan $^{32}$. Tomato seedlings were grown individually in peat moss pellets (Jiffy-9, $50 \mathrm{~mm}$ single, Jiffy Products Ltd.) in a greenhouse under $25 \pm 5^{\circ} \mathrm{C}$ before use. Plant age at the time of inoculation was indicated by the number of leaves on the plant.

\footnotetext{
* Chugoku National Agricultural Experiment Station, Nishifukatsu, Fukuyama 721, Japan 中国農業試験場
} 
Bacteria. Five bacterial strains of $P$. solanacearum, 8107 (biovar IV), 8225 (III), 8231 (I), 8257 (II) and 8266 (IV), were selected from the collection at Chugoku National Agricultural Experiment Station. They were originally isolated from diseased solanaceous plants in Japan and are highly pathogenic to a number of susceptible tomato cultivars ${ }^{22}$. Cultures were stored in $100 \mathrm{~g}$ skimmed milk, $10 \mathrm{~g}$ Na-glutamate per liter of distilled water at $-20^{\circ} \mathrm{C}$ to avoid possible development of avirulent mutants. Prior to inoculation, the stock culture was defrosted and streaked on the selective agar medium of $\mathrm{Hara}$ and $\mathrm{Ono}^{8)}$ and incubated at $30^{\circ} \mathrm{C}$ for 48 hr. Bacteria in virulent colonies ${ }^{10)}$ were collected using a plastic spatula and suspended in distilled water to a concentration of $10^{5}$ to $10^{8} \mathrm{cfu} / \mathrm{ml}$ by means of a colorimeter (Spectronic 20, Bausch \& Lomb).

Inoculation and incubation. Tomato seedlings were inoculated by trimming lateral roots extending from the peat moss pellets, then immersing the pellets in the bacterial suspension in a plastic container $(34 \times 24 \times$ $15 \mathrm{~cm}$ ) for $24 \mathrm{hr}$ in a growth chamber under 30,000 lux light intensity for $12 \mathrm{hr}$ per day at either $30 / 25^{\circ} \mathrm{C}$ or $25 /$ $20^{\circ} \mathrm{C}$ (day/night). Inoculated plants were grown in a plastic container in the growth chamber. To determine the effects of temperature, plant age and inoculum concentration on infection, nine to 12 plants each of Ponderosa, LS-89 or BF-Okitsu 101 seedlings at the 4-5, 6-7, or 8-9 leaf stage were inoculated with $P$. solanacearum 8107 at concentrations of $10^{5}$ to $10^{8} \mathrm{cfu} / \mathrm{ml}$ and grown under $30 / 25^{\circ} \mathrm{C}$ or $25 / 20^{\circ} \mathrm{C}$ for 14 days. The experiment was repeated four times. To compare percentage infection of $P$. solanacearum strains, Ponderosa, LS-89 and BF-Okitsu 101 seedlings at the ten-leaf stage were inoculated with five strains of $P$. solanacearum at $10^{7}$ $\mathrm{cfu} / \mathrm{ml}$ and kept at $30 / 25^{\circ} \mathrm{C}$ for 14 days. The experiment was repeated three times. Seedlings of the three cultivars mock-inoculated with distilled water served as the control.

Recovery of bacterial pathogens from stems of non-symptomatic plants. At 14 days after inoculation, seedlings were indexed for disease severity by giving weights of 4 to 1 for severe to mild wilting and a weight of 0 for no symptoms following the system of Winstead and $\operatorname{Kelman}^{30)}$. Non-symptomatic plants were each examined for possible latent infection as follows: 1 $\mathrm{cm}$ of the stem below the cotyledon was cut and macer-

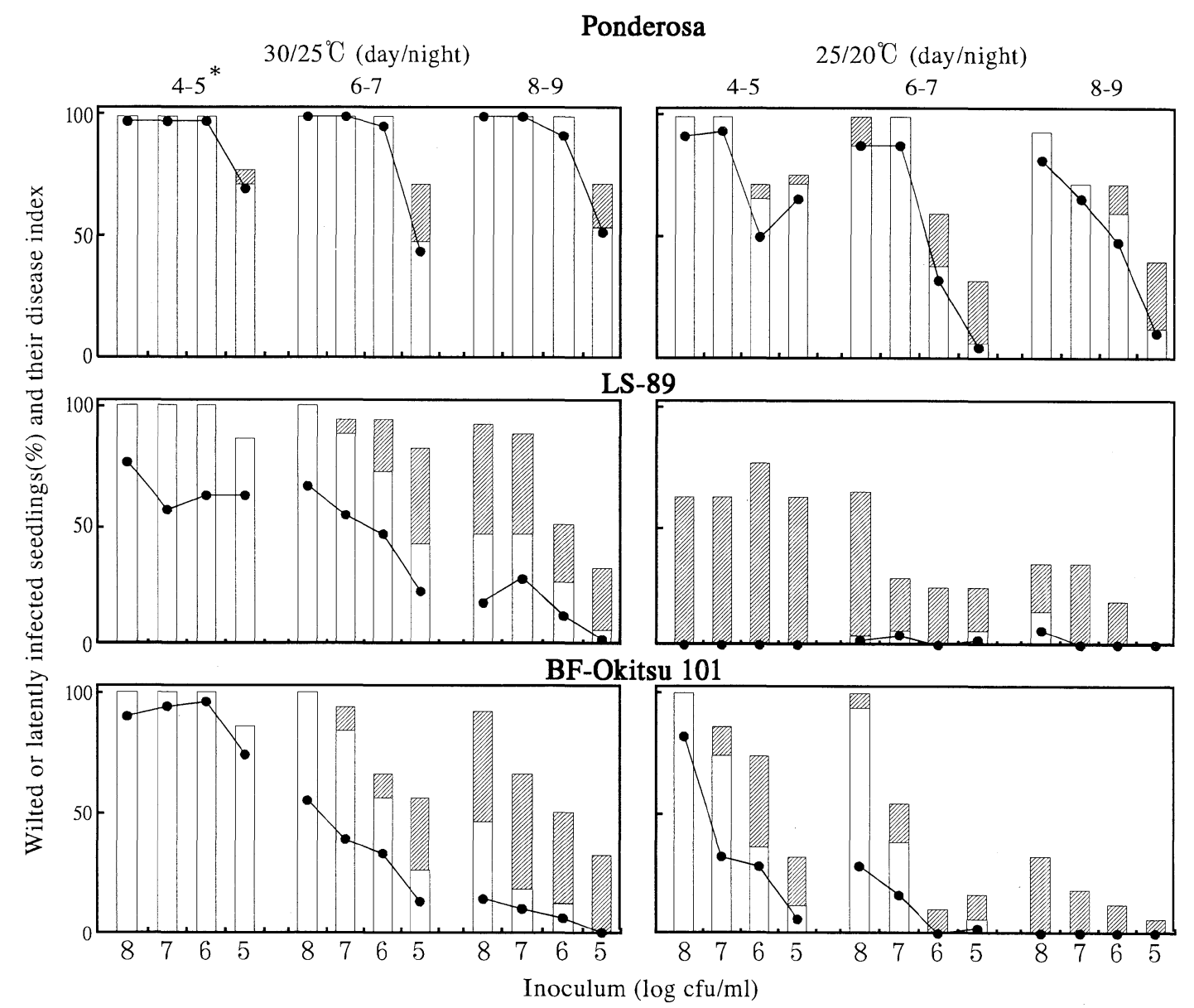

Fig. 1. Percentage of wilted or latently infected seedlings and their disease severity index in Ponderosa, LS-89 and BF-Okitsu 10114 days after root-inoculation with $10^{5}$ to $10^{8} \mathrm{cfu} / \mathrm{ml}$ Pseudomonas solanacearum 8107 at the 4-5, 6-7, or 8-9 leaf stages and grown at $30 / 25^{\circ} \mathrm{C}$ or $25 / 20^{\circ} \mathrm{C}$ (day/night). ${ }^{*}$ : Leaf stage at the time of inoculation, 䐃: Latently infected seedlings (\%), $\square$ : Wilted seedlings (\%), • Disease index. 
ated in a test tube $(1.5 \mathrm{~cm}$ in diameter and $10.5 \mathrm{~cm}$ long) using an aluminum stick with $3 \mathrm{ml}$ sterile distilled water. After incubating the test tube at $5^{\circ} \mathrm{C}$ for $12 \mathrm{hr}, 100 \mu \mathrm{l}$ of the tissue suspension was placed onto the selective agar medium and cultured at $30^{\circ} \mathrm{C}$ for $48 \mathrm{hr}$. Virulent colonies were distinguished by their white or pale red-fluidal appearances from other bacterial colonies on the agar medium $^{8}$. Plants that showed no wilting symptoms but gave positive recovery were considered latently infected.

Effect of rootstocks on latent infection of scions with $P$. solanacearum. Based on the results on the effects of temperature, plant age and inoculum concentration on seedling infection, tweleve plants each of Ponderosa and LS-89 were selected and prepared for scion/rootstock combinations of LS-89 (LS)/Ponderosa (Pon), Pon/LS, LS/LS and Pon/Pon. Grafting was performed using two- or three-leaf stage rootstocks and scions. Rootstocks were topped below their cotyledon, and the cuttings were used as scions. With the graft supported by a ceramic pin (Tsugi-pin, Takii \& Co., Ltd.), the plants were placed in a humid room (100\% relative humidity, $28^{\circ} \mathrm{C}$ ) for two days, then in a shaded house for five days. Grafted plants were root-inoculated at the 6-7 leaf stage as described above with $P$. solanacearum 8107 at $10^{7} \mathrm{cfu} / \mathrm{ml}$ and kept in $25 / 20^{\circ} \mathrm{C}$ for 14 days. Seven and 14 days after inoculation, plants were scored for percentage wilting and disease severity. At 14 days, rootstock stems were excised and macerated for pathogen recovery. Plants of each scion/rootstock combination mock-inoculated with distilled water served as the control. The experiment was repeated four times.

Statistical analysis. The Fisher's exact probability test and the Kruskal-Wallis test were used in analysis on wilting and pathogen recovery, and disease severity index respectively.

\section{RESULTS}

\section{Detection of pathogens in susceptible and resis- tant tomato seedings without symptoms}

In susceptible Ponderosa, most inoculated plants showed severe wilting regardless of leaf stage at the time of inoculation and subsequent growth temperature conditions, except when plants were inoculated at $10^{5}$ or $10^{6} \mathrm{cfu} / \mathrm{ml}$ (Fig. 1). When inoculated at $10^{5}$ or $10^{6} \mathrm{cfu} / \mathrm{ml}$, $20-95 \%$ of plants did not show symptoms. Pathogen was recovered from $15-44 \%$ of those non-symptomatic plants, indicating their latent infection with the bacteria.

In resistant LS-89, percentage wilting of plants inoculated at 4-5 leaf stage with $10^{5}$ to $10^{8} \mathrm{cfu} / \mathrm{ml}$ was higher than $90 \%$ when inoculated plants were grown at $30 / 25^{\circ} \mathrm{C}$, but zero when such plants were grown at $25 / 20^{\circ} \mathrm{C}$ (Fig. 1). Wilting of plants inoculated at 6-7 or 8-9 leaf stage and grown at $30 / 25^{\circ} \mathrm{C}$ decreased when inoculum concentration was lowered. Generally, infected LS-89 plants scored lower severity indices than those in Ponderosa ( $p<0.05$, Kruskal-Wallis test), even under conditions where the percentage wilting reached to nearly $100 \%$. The percentage of latently infected plants was $20-75 \%$ when inoculated plants were grown at $25 / 20^{\circ} \mathrm{C}$. Plants grown at $30 / 25^{\circ} \mathrm{C}$ showed no latent infection when inoculated at the 4-5 leaf stage, but latent infection at $6-41 \%$ at the 6-7 leaf stage and at $26-45 \%$ at the 8-9 leaf stage.

In BF-Okitsu 101, percentage wilting and latent infection of inoculated plants grown at $30 / 25^{\circ} \mathrm{C}$ were similar to those in LS-89 (Fig. 1). At $25 / 20^{\circ} \mathrm{C}$, the percentage of wilted plants was higher than $90 \%$, when plants at the $4-$

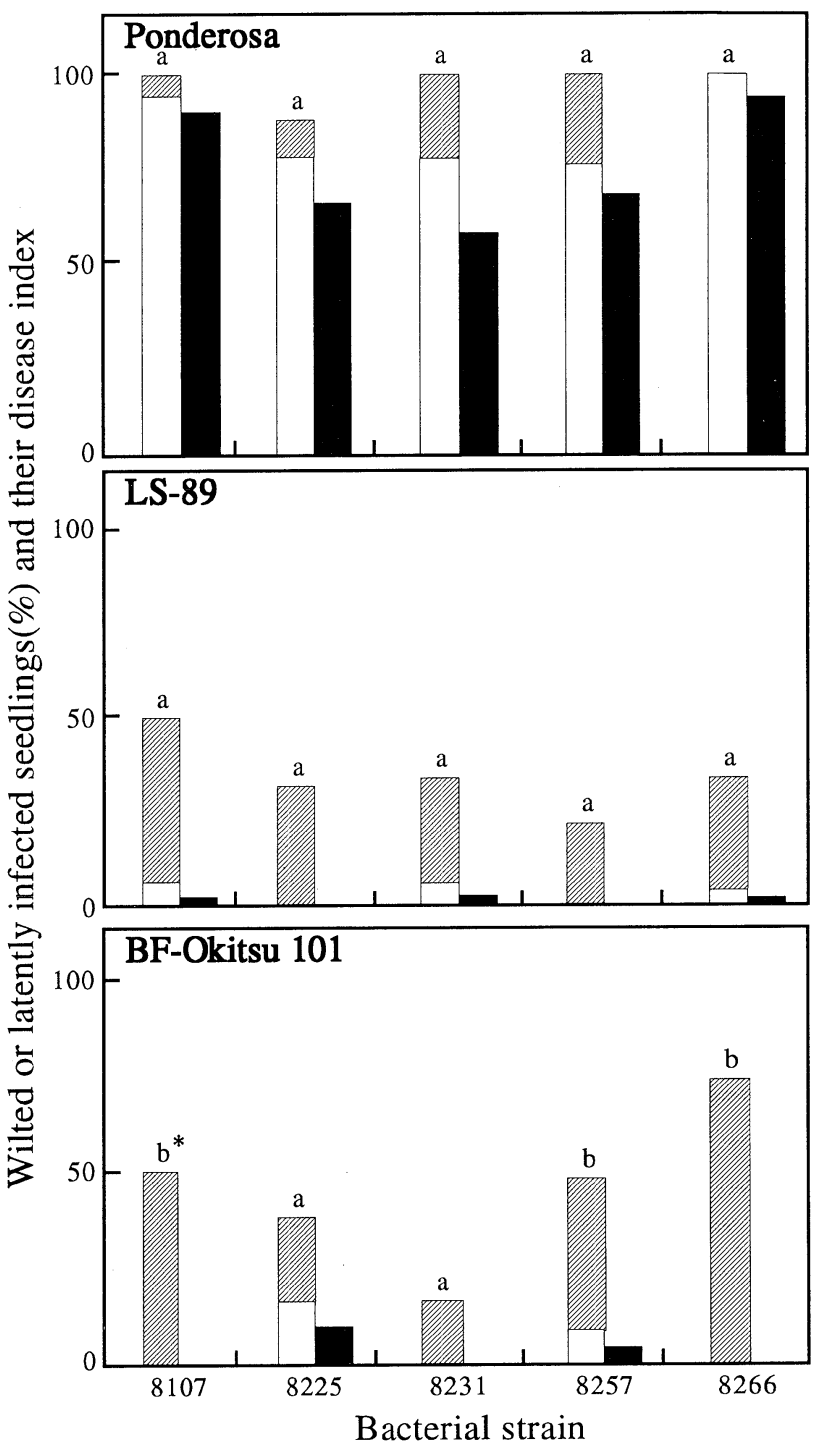

Fig. 2. Percentage of wilted or latently infected seedlings and their disease severity index in Ponderosa, LS-89 and BF-Okitsu 10114 days after root-inoculation at ten leaf stage with five strains of Pseudomonas solanacearum $\left(10^{7} \mathrm{cfu} /\right.$ $\mathrm{ml}$ ) and grown at $30 / 25^{\circ} \mathrm{C}$ (day/night). ${ }^{*}$ : Values followed by different letters in the same column differed significantly in latent infection and wilting at the $0.5 \%$ level (Fisher's exact probability test), 囷: Latently infected seedlings (\%), $\square$ : Wilted seedlings (\%), $\mathbf{\square}$ Disease index. 
Table 1. Percentage wilting and disease severity index of scions 7 and 14 days after rookstocks at the 6-7 leaf stage were root-inoculated with Pseudomonas solanacearum $8107^{\text {a) }}$ and percentage of scions having the pathogen recovered from stems at 14 days

\begin{tabular}{|c|c|c|c|c|c|c|}
\hline \multirow[b]{2}{*}{$\begin{array}{l}\text { Cultivars }^{\mathrm{b})} \\
\text { (scion/ } \\
\text { rootstock) }\end{array}$} & \multicolumn{2}{|c|}{7 days } & \multicolumn{4}{|c|}{14 days } \\
\hline & $\begin{array}{l}\text { Wilted } \\
\text { scions } \\
(\%)\end{array}$ & $\begin{array}{c}\text { Disease } \\
\text { index }\end{array}$ & $\begin{array}{c}\text { Wilted } \\
\text { scions (\%) } \\
\text { (A) }\end{array}$ & $\begin{array}{c}\text { Disease } \\
\text { index }\end{array}$ & $\begin{array}{c}\text { Scions (\%) } \\
\text { with bacteria } \\
\text { recovered (B) }\end{array}$ & $\begin{array}{c}\text { Latent } \\
\text { infection }(\%) \\
(\mathrm{B}-\mathrm{A})\end{array}$ \\
\hline LS/LS & $0 a^{c)}$ & $0 \mathrm{a}$ & $0 \mathrm{a}$ & $0 \mathrm{a}$ & $68.8 \mathrm{a}$ & 68.8 \\
\hline Pon/LS & $29.2 \mathrm{~b}$ & $13.5 \mathrm{a}$ & $58.3 \mathrm{~b}$ & $29.2 \mathrm{~b}$ & $93.8 \mathrm{~b}$ & 35.3 \\
\hline LS/Pon & $91.6 \mathrm{c}$ & $68.8 \mathrm{~b}$ & $91.7 \mathrm{c}$ & $83.9 \mathrm{c}$ & $100 \mathrm{~b}$ & 8.3 \\
\hline Pon/Pon & $81.8 \mathrm{c}$ & $62.5 \mathrm{~b}$ & $100 \mathrm{c}$ & $78.6 \mathrm{c}$ & $100 \mathrm{~b}$ & 0 \\
\hline
\end{tabular}

a) Root-inoculation with $10^{7} \mathrm{cfu} / \mathrm{ml}$ and grown at $25 / 20^{\circ} \mathrm{C}$ (day/night).

b) $\mathrm{LS}=\mathrm{LS}-89$, Pon $=$ Ponderosa.

c) Values followed by different letters in the same column differed significantly in wilted scions or scions (Fisher's exact probability test) at the $0.83 \%$ level, and disease index (Kruskal-Wallis test) at the $5 \%$ level.

5 or $5-6$ leaf stage were inoculated at $10^{8} \mathrm{cfu} / \mathrm{ml}$. The percentage of wilting and latent infection of plants inoculated at the $4-5,6-7$ or 8-9 leaf stage decreased when the inoculum concentration was lowered. Plants inoculated at the 8-9 leaf stage showed no symptoms but had latent infection at $10-40 \%$.

\section{Effect of $P$. solanacearum strains on latent infection of seedlings}

Regardless of the bacterial strain used, $80-100 \%$ of inoculated Ponderosa plants severely wilted by 14 days after inoculation (Fig. 2). In LS-89 and BF-Okitsu 101, plants inoculated with the five strains showed wilting at 5-15\%. Latent infection in non-symptomatic LS-89 and BF-Okitsu 101 plants was $20-80 \%$ with the five strains. The percentage of wilting and latent infection of seedlings was significantly different in BF-Okitsu 101 against the five strains $(p<0.005$, Fisher's exact probability test), but it was not significant in Ponderosa and LS-89 against the same strains.

Effect of rootstocks on latent infection of scions

Table 1 shows percentage wilting and disease severity index of scions grafted on homologous or heterologous rootstocks at 7 and 14 days after inoculation. After 14 days, both LS-89 and Ponderosa scions grafted on Ponderosa had nearly all wilted and had high disease indices (Table 1) as did non-grafted Ponderosa plants treated similarly (Fig. 1). On the other hand, the Ponderosa and the LS-89 scions on LS-89 rootstock reacted differently to infection. In Ponderosa scions on LS-89, wilting reached nearly $60 \%$ by 14 days, but the disease index was relatively low. None of the LS-89 scions on LS-89 wilted but nearly $69 \%$ had latent infection.

\section{DISCUSSION}

Wilting and disease severity in $P$. solanacearuminfected tomato seedlings under the different conditions in these experiments were comparable to those reported earlier ${ }^{12,15,16,18,30)}$. The younger the plants at the time of inoculation, the greater was wilting and disease index. Higher inoculum concentrations and temperature also increased wilting and disease. Resistant rootstock cultivars had less disease when they were maintained at lower temperature after inoculation. Many of the asymptomatic resistant and susceptible plants were shown to be latently infected with $P$. solanacearum as previously reported ${ }^{24,30)}$. Results of these experiments indicate that latent infections are not associated with specific lines or cultivars, but may occur commonly in tomatoes, regardless of susceptibility.

The frequency of latent infection and wilting decreased, when older plants were inoculated and inoculum concentration or incubation temperature was lower. In LS-89, plants grown at $25 / 20^{\circ} \mathrm{C}$ showed almost no symptoms but had latent infection. In potato, latent infection with $P$. solanacearum occurred at $20 / 8^{\circ} \mathrm{C}$ in plants inoculated by stem puncture and at $28 / 16^{\circ} \mathrm{C}$ with infection in the soil ${ }^{4)}$. Though field trials were not included in these experiments, latent infection of tomato may also increase in warmer temperature under natural conditions.

In grafted tomato plants, wilting with $P$. solanacearum infection varied depending on the rootstocks. About a half of Ponderosa scions on LS-89 rootstocks showed wilting, whereas LS-89 scions on LS-89 showed no wilting but had latent infection. Most of those LS-89 rootstocks were likely to have latent infection with $P$. solanacearum, as expected from the results obtained on LS-89 seedlings inoculated with the bacteria. Apparently, infection was due to the pathogen moved from the LS-89 rootstocks into both the Ponderosa and LS-89 scions but only caused wilting in the susceptible Ponderosa. On the other hand, infection with the bacteria did cause wilting of LS-89 scions grafted on Ponderosa at high frequency, which was unexpected from the results on LS-89 seedlings. This may indicate that LS-89 plants are latently infected with $P$. solanacearum but only show wilting when a high concentration of inoculum is supplied from susceptible rootstocks.

In these experiments, the wilting symptoms on Ponderosa grafted on LS-89 appeared later than did symptoms on LS-89 and Ponderosa grafted on Ponderosa. 
The wilting of Ponderosa scions was lower than expected based on the results on non-grafted Ponderosa seedlings and their disease indices were generally lower. The resistance in LS-89 may be similar to that reported in tomato which was associated with the plant's ability to restrict bacterial invasiveness in the lower part of the $\mathrm{stem}^{7}$. Earlier trials using grafted tomato plants had contradictory results. Some studies showed wilting of susceptible scions on resistant rootstocks ${ }^{11,22,26,33)}$ whereas others showed no wilting ${ }^{7,29,33)}$. Wilting of susceptible eggplants grafted on resistant rootstocks has been recorded for both $P$. solanacearum-infested fields ${ }^{11,20)}$ and greenhouse tests ${ }^{21}$. The extent that resistant rootstocks restrict bacterial infection in susceptible scions is likely to vary depending on bacterial strains, environmental conditions and host stage as shown in our study. The wilting of tomatoes and eggplants ${ }^{9)}$ by $P$. solanacearum grafted on resistant rootstocks, previously reported, therefore, may not necessarily be due to a breakdown of the resistance.

In these experiments, the percentage of wilting and latent infection produced by the five strains were significantly different in BF-Okitsu 101 but not in LS-89, indicating that the strains may differ in their ability to invade tomato plants. Similarly, Ciampi \& Sequeira ${ }^{2)}$ reported that strains of $P$. solanacearum differed in their ability to cause latent potato tuber infection in different resistant clones.

In conclusion, the resistant rootstocks used in this study appeared to have insufficient resistance to protect the susceptible scion from bacterial wilt. However, appropriate cultivation practices to keep the environment unfavorable to $P$. solanacearum (i.e., cool ambient temperature, low soil humidity, low soil populations of the pathogen and appropriate planting time) would definitely increase the effectiveness in use of resistant rootstocks. Further study is needed to examine the relationship between latent infection of rootstocks and the wilting of grafted commercial cultivars in the field.

The authors thank Dr. A. Ohuchi, National Institute of Agro-Environmental Sciences for his helpful suggestions and encouragement, and Dr. H. Hibino, Chugoku National Agricultural Experiment Station for critical reading of the manuscript.

\section{Literature cited}

1. Asian Vegetable Research and Development Center (1975). Annual Report for 1974, Shanhua, Taiwan, pp. $52-76$.

2. Ciampi, L., Sequeira, L. and French, E.R. (1980). Latent infection of potato tubers by Pseudomonas solanacearum. Am. Potato J. 57 : 377-386.

3. Enfinger, J.M., McGarter, S.M. and Jaworski, C.A. (1979). Evaluation of chemicals and application methods for control of bacterial wilt of tomato transplants. Phytopathology $69:$ 637-640.

4. French, E.R. and De Lindo, L. (1982). Resistance to
Pseudomonas solanacearum in potato: Specificity and temperature sensitivity. Phytopathology 72: 1408-1412.

5. Goto, M. (1981). Bacterial Plant Pathology, Soft Science, Tokyo, pp. 254-255 (in Japanese).

6. Granada, G.A. and Sequeira, L. (1983). Survival of Pseudomonas solanacearum in soil, rhizosphere, and plant roots. Can. J. Microbiol. 29 : 433-440.

7. Grimault, V. and Prior, P. (1994). Grafting tomato cultivars resistant or susceptible to bacterial wilt: Analysis of resistance mechanisms. J. Phytopathol. 141: 330-334.

8. Hara, H. and Ono, K. (1983). Ecological studies on the bacterial wilt of tobacco, caused by Pseudomonas solanacearum E.F. Smith. I. A selective medium for isolation and detection of Pseudomonas solanacearum. Bull. Okayama Tob. Exp. Stn. 42 : 127-138 (in Japanese with English summary).

9. Hayward, A.C. (1991). Biology and epidemiology of bacterial wilt caused by Pseudomonas solanacearum. Annu. Rev. Phytopathol. 29 : 65-87.

10. Kelman, A. (1954). The relationship of pathogenicity in Pseudomonas solanacearum to colony appearance in a tetrazolium medium. Phytopathology 44 : 693-695.

11. Kobayashi, N. (1993). Biological and integrated control of tomato and eggplant bacterial wilt. Proc. Assoc. Plant Prot. Kyushu 39 : 18-26 (in Japanese with English summary).

12. Krausz, J.P. and Thurston, H.D. (1975). Breakdown of resistance to Pseudomonas solanacearum in tomato. Phytopathology 65 : 1272-1274.

13. McCarter, S.M. and Jaworski, C.A. (1968). Greenhouse studies on the spread of Pseudomonas solanacearum in tomato plants by clipping. Plant Dis. Rep. 52 : 330-334.

14. McCarter, S.M. and Jaworski, C.A. (1969). Field studies on spread of Pseudomonas solanacearum and tobacco mosaic virus in tomato plants by clipping. Plant Dis. Rep. 53 : 942-945.

15. Mew, T.W. and Ho, W.C. (1976). Varietal resistance to bacterial wilt in tomato. Plant Dis. Rep. 60:264-268.

16. Mew, T.W. and Ho, W.C. (1977). Effect of soil temperature on resistance of tomato cultivars to bacterial wilt. Phytopathology 67 : 909-911.

17. Monma, S. and Sakata, Y. (1993). Inheritance of resistance to bacterial wilt in tomato. In Bacterial Wilt. Proceedings of an International Symposium, Kaohsiung, Taiwan (Hartman, G.L. and Hayward, A.C. eds.), ACIAR, Canberra, ACIAR Proc. 45 : 149-153.

18. Ohta, K. and Morita, H. (1981). Occurrence and control of bacterial wilt of tomato in late raising. Bull. Shizuoka Agric. Exp. Stn. 26 : 43-50 (in Japanese with English summary).

19. Okabe, N. (1969). Population changes of Pseudomonas solanacearum and soil microorganisms in artificially infected natural field soils. Bull. Fac. Agric. Shizuoka Univ. 19 : 1-29 (in Japanese with English summary).

20. Okayama, K., Hagiwara, T., Nakano, T. and Tanigawa, M. (1991). Occurrence of Pseudomonas wilt on eggplant grafting resistant rootstock variety Karehen (Solanum sanitowongsei). Proc. Kansai Plant Prot. Soc. 33 : 78 (in Japanese).

21. Ozaki, K. and Kimura, T. (1992). Pathogenicity of 
'bacterial group' of Pseudomonas solanacearum to some host plants. Kinki Chugoku Agric. Res. 83: 11-16 (in Japanese).

22. Ozaki, K. (1992). Studies on pathogenic specialization of Pseudomonas solanacearum in solanaceous plants. Ph. D. thesis, Tokyo Univ., Tokyo, pp. 1-190 (in Japanese).

23. Prior, P. (1990). Aggressiveness of strains of Pseudomonas solanacearum from the French West Indies (Martinique and Guadeloupe) on tomato. Plant Dis. 74 : 962-965.

24. Prior, P., Beramis, M., Chillet, M. and Schmit, J. (1990). Preliminary studies for tomato bacterial wilt (Pseudomonas solanacearum E.F. Sm.) resistance mechanisms. Symbiosis $9: 393-400$.

25. Suzuki, I., Sugawara, Y., Kotani, A., Todaka, S. and Shimada, H. (1964). Studies on breeding eggplants and tomatoes for resistancne to bacterial wilt. I. Investigations on method of evaluating the resistance and on the source of resistance in eggplants and tomatoes. Bull. Hortic. Res. Stn. Jpn. Ser. A. 3 : 77-106 (in Japanese with English summary).

26. Takeuchi, T. (1991). Pathogenicity of Pseudomonas solanacearum isolates from tomato against various tomato cultivars. Proc. Kanto Tosan Plant Prot. Soc. 38 : 75-77 (in Japanese).

27. Tanaka, Y. (1979). Ecological studies on Pseudomonas solanacearum, the pathogen of bacterial wilt of tobacco. Bull. Kagoshima Tob. Exp. Stn. 22 : 1-82 (in Japanese with English summary).

28. Thurston, H.D. (1976). Resistance to bacterial wilt (Pseudomonas solanacearum). In Proceedings of the First International Planning Conference and Workshop on the Ecology and Control of Bacterial Wilt Caused by Pseudomonas solanacearum (Sequeira, L. and Kelman, A. eds.). Raleigh, North Carolina, pp. 58-62.

29. Tikoo, S.K., Mathai, P.J. and Kishan, R. (1979). Successful graft culture of tomato in bacterial wilt sick soils. Curr. Sci. 48 : 259-260.

30. Winstead, N.N. and Kelman, A. (1952). Inoculation techniques for evaluating resistance to Pseudomonas solanacearum. Phytopathology $42: 623-634$.

31. Walter, J.W. (1967). Hereditary resistance to disease in tomato. Annu. Rev. Phytopathol. 5 : 131-162.

32. Yamakawa, K. (1978). Cultivar resistance to Pseudomonas solanacearum in tomato and eggplant. Shokubutsu Boeki (Plant Protection) 32: 197-200 (in Japanese).

33. Yasunaga, T., Aoi, T. and Shigematsu, Y. (1986). Control of bacterial wilt of tomato by grafting. Bull. Ehime Agric. Exp. Stn. 25: 35-41 (in Japanese with English summary).

\section{和 文 摘 要}

中保一浩・高屋茂雄・角田佳則：接ぎ木および自根トマトの 青枯病菌による無病徵感染の条件

青枯病感受性トマト品種ポンデローザ, 抵抗性台木品種 LS89，BF 興津 101 の苗およびポンデローザと LS-89 を台木ある いは穂木として組み合わせた接木苗に青枯病菌Pseudomonas solanacearum を断根接種した。抵抗性, 感受性品種とも萎调 症状を示さなかった苗の多くが無病徵感染していたことを接種 14 日目に茎からの病原細菌の検出により確認した。発病と無病 徵感染を合わせた苗の頻度は，接種時の苗齢が大きいほど，ま た，接種源濃度あるいは接種後の苗の栽培温度が低いほど減少 する傾向が認められた。LS-89 は低温区 (昼 25/夜 20ㄷ) におい てほとんど発病せず 20〜 75\%の苗が無病徴感染していた。青枯 病菌 5 菌株に対しポンデローザ，LS-89 の苗では菌株間におけ る発病と無病徵感染を合わせた苗の割合に差はなかったが, $\mathrm{BF}$ 興津 101 の苗では有意な差異が認められた。ポンデローザ 台に接いだポンデローザと LS-89 はほとんどすべてが萎调し た。一方，LS-89 台に接いだポンデローザは $60 \%$ 萎调したが， LS-89 は病徴を示さなかった。この場合，LS-89 の 69\%および 萎调を示さなかったポンデローザの $35 \%$ は無病徵感染してい た。以上の結果，抵抗性台木に接いだ感受性穂木の発病は, 無病 徵感染している台木からの病原細菌の移行により容易に生じる ことが示された。 